\title{
THE STUDY OF SERUM LEVAL OF GLUCOSE, CHOLESTROL, TRIGLYCERIDE, ALBUMIN AND TOTAL PROTEIN IN REPEAT BREEDER NATIVE COWS IN AHWAZ(IRAN)
}

\author{
Saad Goorani Nejad and Javad Cheraghi \\ Faculty of Veterinary Medicine Shahid Chamran University. Ahwaz. Iran
}

\begin{abstract}
A low plan of nutrition due to a lack of sufficient intake of carbohydrate, proteins and other elements necessary to maintain body weight may cause a failure in fertility, therefore, this study was conducted to evaluate the serum level of glucose, cholesterol, triglyceride, albumin and total protein in repeat breeder cows in ahwaz city (central of khozestan state). Blood samples were Collected from jugular vein of 13 primiparous and 22 multiparous repeat breeder cows, and controls ( 26 primiparous cows and 44 multiparous cows) since summer of 1998 till summer of 1999 . The difference between serum glucose, cholesterol, triglyceride, albumin and total protein values for affected and control cows were evaluated statistically with case-control matching intact by a 2-tailed paired $\mathrm{t}$ - test. Results showed that mean $( \pm$ SEM) value of blood serum glucose $(\mathrm{mg} / \mathrm{dl})$ of case and control groups was $60.29 \pm 1.53$ and $79.84 \pm 1.20$ respectively, thus, the mean value of serum glucose in repeat breeder cows was significantly lower than control group $(\mathrm{P}<0.05)$. Blood glucose level of primiparous repeat breeder (13 cows) and primiparous normal cows $(n=26)$ was $59.58 \pm 2.44$ and 81.14 \pm 2.26 respectively, and the difference was significant $(\mathrm{P}<0.05)$, for multiparous repeat breeder $(\mathrm{n}=$ $22)$ and normal cows $(n=44)$ was $60.72 \pm 2.01$ and $79.06 \pm 1.39$ respectively, and the difference was significant $(\mathrm{P}<0.05) . \mathrm{Mea}( \pm \mathrm{SEM})$ value of blood serum cholesterol $(\mathrm{mg} / \mathrm{dl})$ in case group $(\mathrm{n}=35)$ and control group $(n=70)$ was $86.18 \pm 2.44$ and $87.20 \pm 2.83$ respectively, thus blood serum cholesterol level of cases was significantly lower than control group $(\mathrm{P}<0.05)$. Mean value of serum cholesterol in 13 primiparous of case $(82.01 \pm 3.67)$ and 26 control primiparous $(82.54 \pm 4.77)$, and the difference was not significant $(\mathrm{P}>0.05)$. Mean $( \pm \mathrm{SEM})$ value of blood serum triglyceride $(\mathrm{mg} / \mathrm{dl})$ in case group $(n=35)$ and control group $(n=70)$ was $64.58 \pm 2.95$ and $97.92 \pm 1.74$ respectively, and the difference was significant $(\mathrm{P}<0.05)$. Mean serum triglyceride level of 13 multiparous cases $(65.52+$ 4.09) was significantly lower than 26 primiparous control $(99.98+2.84),(\mathrm{P}<0.05)$. Mean serum triglyceride level of 22 multiparous cases $(64.02 \pm 4.08)$ was significantly lower than 44 multiparous control $(96.69 \pm 2.18),(\mathrm{P}<0.05)$. Mean $( \pm \mathrm{SEM})$ value of blood serum albumin $(\mathrm{g} / \mathrm{dl})$ in case group $(\mathrm{n}=$ $35)$ and control group $(\mathrm{n}=70)$ was $2.49 \pm 0.07$ and $2.51 \pm 0.05$ respectively, and the difference was not significant $(\mathrm{P}>0.05)$. and in primiparous $\operatorname{cases}(\mathrm{n}=13)$ lower than control group $(\mathrm{n}=26), 2.53 \pm$ 0.13 and $2.56 \pm 0.07$, respectively, but the difference was not significant, $(\mathrm{P}>0.05)$.mean albumin level of multiparous cases $(n=22)$ lower than control group $(n=44), 2.46 \pm 0.08$ and $2.48 \pm 0.06$, respectively, but the difference was not significant, $(\mathrm{P}>0.05)$. Mean $( \pm \mathrm{SEM})$ value of blood serum total protein $(\mathrm{g} / \mathrm{dl})$ in cases group $(\mathrm{n}=35)$ and control group $(\mathrm{n}=70)$ was $7.46 \pm 0.15$ and $8.03 \pm 0.09$, respectively, and the difference was significantly, $(\mathrm{P}<0.05)$.mean serum total protein level of primiparous cases $(n=13)$ was lower than primiparous control $(n=26), 7.69 \pm 0.28$ and $7.87 \pm 0.18$, respectively, but the difference was not significant, $(\mathrm{P}>0.05)$. and in multiparous cases $(\mathrm{n}=22)$ was lower than multiparous control $(n=44), 7.33 \pm 0.16$ and $8.12 \pm 0.1$, respectively, and the difference was significant, $(\mathrm{P}<0.05)$. The conclusion of this study showed that deficiency of both energy and protein in affected cows is prevalent.
\end{abstract}

